\title{
PENURUNAN KADAR Hg PADA IKAN BELANAK (Mugil dussumieri) DENGAN MENGGUNAKAN FILTRAT TOMAT (Solanum Iycopersicum) 2017
}

\author{
Nia Nur Azizah, Narwati, Hadi Suryono
}

\begin{abstract}
ABSTRAK
Ikan belanak merupakan hasil laut yang banyak dikonsumsi oleh masyarakat. Salah satu perairan yang banyak ditemukan ikan belanak adalah pantai kenjeran surabaya. Perairan pantai kenjeran surabaya telah tercemar logam berat merkuri $(\mathrm{Hg})$ oleh limbah industri dan rumah tangga sehingga biota yang hidup dalam perairan tersebut juga terkontaminasi merkuri $(\mathrm{Hg})$. Tujuan penelitian ini adalah untuk mengetahui pengaruh perbedaan lama waktu perendaman larutan filtrat tomat konsentrasi $50 \%$ terhadap kadar merkuri dalam ikan belanak.

Penelitian ini menggunakan rancangan one group pretest posttest design dengan empat perlakuan yaitu lama waktu perendaman 60 menit, 90 menit, 120 menit, 150 menit dalam larutan filtrat tomat $50 \%$. Peneliti menggunakan uji paired t test dan uji anova untuk menganalisis penelitian ini.

Hasil penelitian menunjukkan bahwa kadar rata-rata $\mathrm{Hg}$ sebelum perlakuan adalah 0,014 $\mathrm{mg} / \mathrm{kg}$. Setelah perlakuan, penurunan $\mathrm{Hg}$ pada lama waktu perendaman 60 menit sebesar $14 \%$, 90 menit sebesar $22 \%$, 120 menit sebesar $64 \%$, dan 150 menit sebesar $86 \%$

Dapat disimpulkan bahwa ada pengaruh lama waktu perendaman filtrat tomat terhadap penurunan kadar logam berat $\mathrm{Hg}$ dalam ikan belanak. Disarankan kepada orang untuk merendam bahan makanan sebelum konsumsi dengan menggunakan tomat filtrat karena bisa mengurangi kadar logam berat $\mathrm{Hg}$.
\end{abstract}

Kata Kunci : Ikan Belanak, Logam Berat Hg, Filtrat Tomat

\section{PENDAHULUAN}

Ikan belanak memiliki nilai ekonomis yang cukup tinggi serta banyak di konsumsi oleh masyarakat serta populasinya tersebar di perairan tropis dan subtropis. Ikan Belanak merupakan salah satu ikan tangkap yang dapat dijumpai di perairan Pantai Kenjeran Surabaya. Potensi Pantai Kenjeran dalam mencemari lingkungan disebabkan pantai tersebut menerima limbah padat dan cair yang mengandung logam berat dari tujuh sungai besar yang bermuara di perairan tersebut. (Dewi et al. 2010). Sebanyak 98 industri dari 483 industri yang berada di Daerah Aliran Sungai (DAS) Brantas, membuang limbahnya di Kali Surabaya (Ampuh, 2013). Salah satu logam berat yang mencemari perairan Pantai Kenjeran adalah $\mathrm{Hg}$. Kadar $\mathrm{Hg}$ dalam perairan Pantai Kenjeran adalah 0,00097 ppm (Taftazani, 2007).

Merkuri yang terdapat di perairan dapat menyebabkan efek toksik bagi manusia yang mengkonsumsi biota dari perairan tersebut. (Palar, 2010). Masuknya Hg kedalam tubuh manusia dapat melalui mekanisme pencernaan yaitu mulut dengan mengkonsumsi ikan yang tercemar $\mathrm{Hg}$. $\mathrm{Hg}$ pada ikan masuk melalui jalur rantai makanan. Dampak mengkonsumsi ikan yang mengandung $\mathrm{Hg}$ adalah kerusakan syaraf pusat (Widowati, 2008).Kasus keracunan akibat mengkonsumsi ikan yang tercemar $\mathrm{Hg}$ adalah keracunan di Minamata, Jepang tahun 1975. Para ibu yang mengkonsumsi ikan dari perairan tersebut melahirkan bayi dengan kerusakan otak disebabkan karena metil merkuri dapat masuk kedalam placenta dan merusak janin serta mengganggu saluran darah ke otak (Zulkifli, 2006).

Kasus lain terjadi pencemaran $\mathrm{Hg}$ di Teluk Buyat Sulawesi Utara tahun 1996. Puluhan ikan mati dan warga desa mengalami gejala penyakit seperti sakit kepala yang berulang-ulang, gatal-gatal, mual, muntah, pembengkakan beberapa bagian tubuh, hingga pingsan mendadak (Lutfillah, 2011). Kadar $\mathrm{Hg}$ dalam darah warga Buyat adalah 0,0239 ppm (Widowati, 2008). 
Kadar tersebut dapat memberikan efek berbahaya bagi tubuh misalnya kerusakan sistem saraf pusat karena berdasarkan SNI No 7387 tahun 2009 toksisitas $\mathrm{Hg}$ adalah $0,005 \mathrm{mg} / \mathrm{kg}$ bb. Kasus lain terjadi di Pantai Kenjeran Surabaya. Terjadinya peningkatan kadar $\mathrm{Hg}$ pada rambut nelayan di wilayah tersebut sekitar 265,09 ppb menyebabkan gangguan kesehatan seperti ginjal dan hati. (Sudarmaji et al. 2005)

Akumulasi $\mathrm{Hg}$ pada ikan yang dijumpai di Pantai Kenjeran Surabaya ditemukan pada ikan belanak. Diketahui dari penelitian (Taftazani, 2007) kadar $\mathrm{Hg}$ dalam ikan belanak sebesar 0,8466 ppm. Kadar $\mathrm{Hg}$ tersebut telah melebihi nilai ambang batas yang ditetapkan oleh SNI 7387 tahun 2009 tentang batas maksimum cemaran logam berat dalam pangan yakni sebesar 0,5 ppm. Hasil pemeriksaan yang dilakukan peneliti tentang kadar $\mathrm{Hg}$ pada ikan belanak dengan berat kurang lebih 100 gram sebesar 0,007 ppm. Meskipun Kadar tersebut tidak melebihi nilai ambang batas namun tetap dapat berpotensi membahayakan kesehatan jika terus dikonsumsi karena $\mathrm{Hg}$ dapat terakumulasi dalam tubuh manusia. Potensi risiko yang dapat terjadi karena mengkonsumsi ikan tercemar $\mathrm{Hg}$ adalah kerusakan sistem saraf pusat (Widowati， 2008 : 146). Oleh karena itu perlu dilakukan upaya dalam meminimalisasi kadar $\mathrm{Hg}$ pada ikan belanak tersebut. Salah satunya dengan menggunakan sekuestran (zat pengikat logam) berupa asam sitrat.

Tomat merupakan salah satu komoditi di Jawa Timur. Produksi tomat pada tahun 2014 mencapai 64,851 ton (Kementerian Pertanian RI, 2014) sehingga jumlahnya banyak dan mudah ditemui. Tomat juga bernilai ekonomis sehingga dapat dijangkau oleh masyarakat. Tomat dapat dimanfaatkan untuk menurunkan kadar logam berat dalam makanan karena kandungan asam sitrat. Menurut Saputri et al. (2014) Asam sitrat akan menghasilkan ion sitrat yang akan bereaksi dengan ion logam membentuk ion kompleks, sehingga logam berat tersebut keluar dari bahan makanan. Tujuan dari penelitian ini adalah untuk mengetahui perbedaan penurunan kadar $\mathrm{Hg}$ pada ikan belanak (Mugil dussumieri) dengan lama waktu perendaman filtrat tomat sayur yang berbeda.

\section{METODE PENELITIAN}

Penelitian ini adalah penelitian eksperiment menggunakan metode One Group Pretest Posttest dengan satu faktor perlakuan, yaitu perbedaan lama waktu perendaman ( 60 menit, 90 menit, 120 menit, 150 menit) dalam larutan filtrat tomat $50 \%$. Penelitian ini dilakukan dengan 6 kali pengulangan.

Tahapan penelitian yang dilakukan ada 2 , yaitu perendaman ikan belanak dalam filtrat tomat dan analisis kadar $\mathrm{Hg}$ pada ikan belanak setelah dengan menggunakan AAS (Atomic Absorption Spectrometry) Type Aurora 8000 dan panjang gelombang

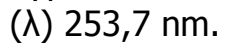

Pembuatan filtrat tomat, dengan menghaluskan tomat menggunakan blender. Selanjutnya filtrat tomat disaring dengan saringan. Kemudian untuk memperoleh konsentrasi filtrat tomat $50 \%$ digunakan filtrat tomat dengan volume 50 $\mathrm{ml}$ ditambah dengan aquadest $50 \mathrm{ml}$. 


\section{HASIL DAN PEMBAHASAN}

Kadar Hg Sebelum dan Sesudah Perlakuan Perendaman.

Hasil Pemeriksaan kadar $\mathrm{Hg}$ pada ikan belanak sebelum dilakukan perendaman dapat

dilihat pada tabel 1.

Tabel 1 Kadar Hg Pada Ikan Belanak Sebelum Dilakukan Perlakukan Perendaman Pada Filtrat Tomat

\begin{tabular}{|c|c|c|c|c|c|c|c|c|c|}
\hline \multirow[t]{2}{*}{$\begin{array}{c}\text { KODE } \\
\text { SAMPEL }\end{array}$} & \multicolumn{6}{|c|}{$\begin{array}{c}\text { KADAR LOGAM BERAT Hg PADA IKAN BELANAK } \\
\text { PADA PENGULANGAN KE- } \\
\text { (Mg/Kg) }\end{array}$} & \multirow[t]{2}{*}{$\begin{array}{l}\text { JUMLAH } \\
\text { (Mg/Kg) }\end{array}$} & \multirow{2}{*}{$\begin{array}{c}\text { RATA - } \\
\text { RATA } \\
\text { (Mg/ } \\
\text { Kg) }\end{array}$} & \multirow[t]{2}{*}{$\begin{array}{c}\text { STD } \\
\text { SNI } \\
(\mathbf{M g} / \mathbf{K g})\end{array}$} \\
\hline & 1 & 2 & 3 & 4 & 5 & 6 & & & \\
\hline K & 0,011 & 0,015 & 0,014 & 0,016 & 0,013 & 0,014 & 0,083 & 0,014 & 0,5 \\
\hline
\end{tabular}

Sumber : Data Primer

Keterangan

$\mathrm{K} \quad$ : Kelompok kontrol sampel ikan belanak

Hasil pemeriksaan laboratorium rata - rata kadar $\mathrm{Hg}$ pada ikan belanak sebelum perlakuan perendaman sebesar $0,014 \mathrm{mg} / \mathrm{kg}$. Meskipun kadar tersebut tidak melebihi nilai ambang batas yang ditetapkan SNI 7387 tahun 2009 yakni sebesar 0,5 mg/kg namun tetap dapat berpotensi membahayakan kesehatan jika terus dikonsumsi karena $\mathrm{Hg}$ dapat terakumulasi dalam tubuh manusia (Widowati, 2008).

Tabel 2 Kadar Hg Pada Ikan Belanak Sesudah Dilaksanakan Perlakuan Perendaman Pada Filtrat Tomat

\begin{tabular}{|c|c|c|c|c|c|c|c|c|}
\hline \multirow[t]{2}{*}{$\begin{array}{c}\text { KODE } \\
\text { SAMPEL }\end{array}$} & \multicolumn{6}{|c|}{$\begin{array}{c}\text { KADAR LOGAM BERAT Hg PADA IKAN BELANAK } \\
\text { PADA PENGULANGAN KE- } \\
(\mathrm{Mg} / \mathrm{Kg})\end{array}$} & \multirow[t]{2}{*}{$\begin{array}{l}\text { JUMLAH } \\
\text { (Mg/Kg) }\end{array}$} & \multirow[t]{2}{*}{$\begin{array}{c}\text { RATA- } \\
\text { RATA } \\
\text { (Mg/ } \\
\text { Kg) }\end{array}$} \\
\hline & 1 & 2 & 3 & 4 & 5 & 6 & & \\
\hline A & 0,010 & 0,013 & 0,011 & 0,014 & 0,011 & 0,012 & 0,071 & 0,012 \\
\hline B & 0,010 & 0,012 & 0,012 & 0,011 & 0,010 & 0,011 & 0,066 & 0,011 \\
\hline C & 0,006 & 0,005 & 0,004 & 0,006 & 0,004 & 0,005 & 0,03 & 0,005 \\
\hline D & 0,003 & 0,002 & 0,002 & 0,002 & 0,003 & 0,002 & 0,014 & 0,002 \\
\hline
\end{tabular}

Sumber : Data Primer

Keterangan :

A :Kelompok sampel ikan belanak direndam dalam larutan filtrat tomat selama 60 menit

B :Kelompok sampel ikan belanak direndam dalam larutan filtrat tomat selama 90 menit

C :Kelompok sampel ikan belanak direndam dalam larutan filtrat tomat selama 120 menit

D :Kelompok sampel ikan belanak direndam dalam larutan filtrat tomat selama 150 menit

Hasil pemeriksaan laboratorium kadar $\mathrm{Hg}$ pada ikan belanak sesudah perlakuan perendaman menunjukkan adanya penurunan kadar $\mathrm{Hg}$ dalam ikan belanak. hal ini diduga karena adanya kandungan asam sitrat dalam larutan filtrat tomat tersebut. Asam sitrat menghasilkan Ion sitrat yang akan bereaksi dengan ion logam membentuk ion kompleks yang mudah larut dalam air (Saputri et al. 2014). Pada penelitian ini penurunan kadar $\mathrm{Hg}$ pada ikan belanak dengan perendaman larutan filtrat tomat $50 \%$ tertinggi yaitu saat perendaman 150 menit dari pada perendaman 60 menit, 90 menit, dan 120 menit. 
Pada penelitian Ulfah el at. (2014), menunjukkan adanya penurunan $\mathrm{Pb}$ pada ikan keting dengan perendaman filtrat kulit nanas yang mengandung asam sitrat selama 60 menit terjadi penurunan yang lebih tinggi daripada perendaman selama 30 menit.

Menurut Ulfah et al. ( 2014 ), semakin lama waktu perendaman maka semakin besar penurunan kadar logam berat dalam tubuh ikan karena semakin lama nya waktu yang diberikan kepada ion sitrat dalam bereaksi dengan ion logam sehingga semakin banyaknya ikatan kompleks logam protein yang lepas.

\section{Perbandingan Kadar Hg Pada Ikan Belanak Sebelum Dan Sesudah Perlakuan} Perendaman.

Perbandingan penurunan kadar $\mathrm{Hg}$ pada ikan belanak dapat dilihat pada tabel 3.

Tabel 3. Penurunan Kadar Hg Pada Ikan Belanak Sebelum Dan Sesudah Perlakuan Perendaman

\begin{tabular}{cccccc}
\hline NO & KODE & $\begin{array}{c}\text { RATA - RATA KADAR LOGAM } \\
\text { BERAT Hg PADA IKAN } \\
\text { BELANAK (Mg/Kg) }\end{array}$ & $\begin{array}{c}\text { PENURUNAN } \\
\text { KADAR } \\
\text { LOGAM } \\
\text { BERAT Hg } \\
\text { (Mg/Kg) }\end{array}$ & $\begin{array}{c}\text { PENURUNAN } \\
\text { KADAR } \\
\text { LOGAM } \\
\text { BERAT Hg } \\
\text { (\%) }\end{array}$ \\
\cline { 3 - 4 } & SEBELUM & SESUDAH & & \\
1. & $\mathrm{A}$ & 0,014 & 0,012 & 0,002 & 14,286 \\
2. & $\mathrm{B}$ & 0,014 & 0,011 & 0,003 & 21,429 \\
3. & $\mathrm{C}$ & 0,014 & 0,005 & 0,009 & 64,286 \\
4. & $\mathrm{D}$ & 0,014 & 0,002 & 0,012 & 85,714 \\
\hline
\end{tabular}

Berdasarkan hasil uji beda statistic menunjukkan ada perbedaan yang signifikan antara kadar $\mathrm{Hg}$ sebelum dan sesudah perlakuan perendaman dengan larutan filtrat tomat konsentrasi $50 \%$ dengan berbagai lama waktu perendaman.

Penurunan kadar $\mathrm{Hg}$ pada ikan belanak disebabkan karena adanya kandungan asam sitrat dalam larutan filtrat tomat tersebut. Hal ini terbukti pada hasil penelitian Nasution et al. (2015) yang menunjukkan adanya penurunan kadar $\mathrm{Hg}$ pada ikan tongkol dengan menggunakan larutan jeruk nipis yang mengandung asam sitrat terjadi penurunan hingga $61,60 \%$.

Asam sitrat bersifat sebagai agen pengkelat dimana senyawa ini memiliki kemampuan untuk mengikat logam - logam divalen seperti $\mathrm{Mn}, \mathrm{Mg}, \mathrm{Hg}$, Fe. Proses keseimbangan pengikatan logam merupakan proses pembentukan kompleks ion logam dengan ligan (sekuestran).

Secara umum keseimbangan tersebut ditulis sebagai berikut :

$\begin{array}{ll}\mathrm{L}+\mathrm{S} \longrightarrow \mathrm{LS} \\ \text { Keterangan : } & \\ \mathrm{L} & =\text { ion logam } \\ \mathrm{S} & =\text { ligan (sekuestran) } \\ \mathrm{LS} & =\text { kompleks ligan }\end{array}$


Proses pengikatan ion logam dengan pengikat logam berawal dari tiga gugus karboksil $(\mathrm{COOH})$ dalam asam sitrat yang dapat melepaskan proton dalam larutan. dan ion yang dihasilkan adalah ion sitrat (Noto, 2010). Ion sitrat dapat bereaksi dengan ion logam karena logam berat dapat berikatan dengan atom yang memiliki ion bebas, sedangkan asam sitrat memiliki empat elektron bebas pada gugus karboksil (Saputri et al. 2014). Disamping itu logam - logam pada umumnya dapat membentuk ikatan dengan bahan organik alam maupun buatan. Proses pembentukan ikatan tersebut dapat terjadi melalui pembentukan garam organik dengan gugus karboksilat misalnya asam sitrat (Sakinah, 2013). Ion sitrat yang bereaksi dengan ion logam membentuk ion kompleks yang mudah larut dalam air (Saputri et al. 2014).

Ion logam yang terdapat dalam tubuh organisme hampir semuanya berikatan dengan protein. Interaksi kompleks antara ion logam dengan protein secara metaloenzim (protein berikatan secara kuat dengan ion logam membentuk ikatan yang stabil) dan metal protein ( protein yang berikatan dengan logam di dalam tubuh dan ion logamnya mudah saling bertukar dengan protein yang lain. (Ulfah et al. 2014).

Proses masuknya ion sitrat dalam larutan filtrat tomat kedalam daging ikan dengan cara penetrasi (peresapan). Menurut Mus et al. (2014) bahwa faktor yang mempengaruhi penetrasi suatu larutan ke dalam daging yaitu bentuk daging dan ketebalan daging tersebut. Selain itu konsentrasi larutan juga mempengaruhi penetrasi kedalam daging. Semakin tinggi konsentrasi larutan filtrat maka semakin pekat larutan filtrat tersebut karena semakin sedikitnya kadar air dalam larutan sehingga sulit untuk penetrasi kedalam daging. Menurut Purnamasari et al. (2013) semakin tinggi konsentrasi akan mengakibatkan penurunan kadar air dan meningkatnya kadar protein. $\mathrm{Hal}$ ini dibuktikan dalam penelitian Galih et al. (2016) bahwa konsentrasi 75\% larutan filtrat tomat lebih efektif dalam menurunkan $\mathrm{Pb}$ pada kerang hijau daripada larutan filtrat tomat konsentrasi $100 \%$. karena semakin meningkatnya konsentrasi menyebabkan meningkatnya kepekatan filtrat tomat sehingga sulit berpenetrasi kedalam daging kerang.

Tingginya konsentrasi juga menyebabkan pengerutan pada daging sehingga larutan filtrat akan sulit penetrasi kedalam daging. Menurut Faisal (2015), penggunaan bahan yang berbasis asam tinggi tidak disarankan karena daging dapat mengerut dan menjadi keras.

Lamanya waktu perendaman larutan filtrat tomat juga mempengaruhi penetrasi kedalam daging. Semakin lama waktu perendaman maka penetrasi larutan filtrat tomat kedalam daging ikan semakin dalam. Menurut Mus (2004), bahwa semakin lama proses perendaman maka semakin dalam pula penetrasi larutan kedalam daging. Hal ini dibuktikan dengan penelitian Ulfah et al. (2014), semakin lama perendaman ikan keting dalam larutan filtrat kulit buah nanas maka semakin besar penurunan kadar $\mathrm{Pb}$ pada daging ikan keting. Demikian hal nya dengan penelitian ini bahwa lama waktu perendaman juga mempengaruhi penurunan kadar $\mathrm{Hg}$ pada ikan belanak. Penurunan kadar $\mathrm{Hg}$ terjadi karena kondisi ikan menjadi asam. Kondisi asam ini karena penurunan $\mathrm{pH}$ yang disebabkan oleh asam sitrat. Menurut Surianti et al. (2012), semakin lama waktu perendaman maka daging tersebut akan semakin asam. Menurut Ulfah et al. (2014), kondisi yang semakin asam akan menyebabkan semakin banyak jumlah hidrogen yang berkompetisi dengan ion logam sehingga ikatan logam dan protein semakin berkurang dan mudah lepas. Ion - ion logam tersebut keluar dari dalam daging ikan dan bereaksi dengan ion sitrat membentuk garam sitrat yang larut dalam air sehingga terjadinya penurunan kadar $\mathrm{Hg}$ dalam ikan tersebut. Hal ini dibuktikan dalam penelitian Armada (2009), bahwa penurunan Pb pada udang windu dengan perendaman larutan jeruk nipis yang mengandung asam sitrat selama 60 menit terjadi penurunan sebesar 64,46 \% sedangkan selama 30 menit terjadi penurunan sebesar $48,40 \%$. Metil merkuri mudah berikatan dengan gugus sulfidhril yang terdapat dalam berbagai protein (Yanuar, 2008). Apabila merkuri berikatan dengan sulfidhril, merkuri divalen akan menggantikan atom 
hidrogen membentuk merkaptida (Endrinaldi, 2009). Penambahan asam dapat mendenaturasikan protein. Denaturasi dikatakan sebagai suatu proses terpecahnya ikatan hydrogen, ikatan garam, dan terbentuknya lipatan atau wiru molekul (Triyono, 2010) Dengan terpecahnya ikatan hidrogen yang digantikan oleh merkuri maka dengan penambahan asam, merkuri akan terlepas dari protein.

Berdasarkan hasil uji anova yaitu $\mathrm{p}=$ $0,000<a(0,05)$ menunjukkan ada perbedaan lama waktu perendaman dengan filtrat tomat selama 60 menit, 90 menit, 120 menit, 150 menit terhadap penurunan logam berat $\mathrm{Hg}$ pada ikan belanak.

\section{KESIMPULAN DAN SARAN \\ Kesimpulan}

a. Kadar $\mathrm{Hg}$ rata - rata pada ikan belanak sebelum dilakukan perlakuan perendaman masih memenuhi nilai ambang batas menurut SNI 7387 tahun 2009 yakni sebesar $0,5 \mathrm{mg} / \mathrm{kg}$ sedangkan kadar $\mathrm{Hg}$ pada ikan belanak sesudah dilakukan perlakuan perendaman terjadi penurunan kadar $\mathrm{Hg}$ pada ikan belanak tersebut.

b. Kadar $\mathrm{Hg}$ pada ikan belanak sesudah perlakuan perendaman dalam larutan filtrat tomat lebih rendah dibandingkan dengan sebelum perlakuan perendaman. Besarnya penurunan kadar $\mathrm{Hg} \pm 0,012 \mathrm{mg} / \mathrm{kg}$ dengan persentase $86 \%$.

c. Ada perbedaan lama waktu perendaman filtrat tomat terhadap penurunan kadar $\mathrm{Hg}$ pada ikan belanak $p=0,000<a(0,05)$. Semakin lama waktu perendaman maka semakin tinggi penurunan kadar $\mathrm{Hg}$ pada ikan belanak.

\section{Saran}

a. Bagi Masyarakat

Rendaman filtrat tomat dapat digunakan sebagai salah satu upaya dalam menurunkan kadar $\mathrm{Hg}$ pada bahan makanan khususnya ikan.

b. Bagi Peneliti Lain Diperlukan adanya penelitian lanjutan mengenai :
1) Mengembangkan penggunaan filtrat tomat terhadap penurunan logam berat lainnya.

2) Kandungan asam lainnya dalam proses penurunan logam berat $\mathrm{Hg}$

3) Penambahan variable konsentrasi larutan dan lama waktu perendaman.

\section{DAFTAR PUSTAKA}

Ampuh, 2013. 1.004 Perusahaan Potensi Cemari Sungai Di Surabaya. (http://ampuh.org/2013/10/1-004perusahaan-potensi-cemari-sungai-disurabaya/ )

Armada.F, 2009. Studi Pemanfaatan Buah Jeruk Nipis ( Citrus aurantifolia ) Sebagai Chelator Logam Pb dan Cd Dalam Udang Windu ( Panaeus monodon ). Skripsi Universitas Sumatera Utara.

Dewi.P., Rahayu.U., dan Koderi, 2010. Penurunan Kadar Merkuri ( $\mathrm{Hg}$ ) Pada Ikan Pari Ayam (Dasyatis sephen) Pantai Kenjeran Surabaya Dengan Cara Dipanggang, Direbus, dan Digoreng Tahun 2010. Poltekkes Kemenkes Surabaya. pp 240-244.

Endrinaldi, 2009. Logam - Logam Berat Pencemar Lingkungan Dan Efek Terhadap Manusia. Jurnal Kesehatan Masyarakat Vol (4) : 1.

Faisal.A., 2015. Karakteristik Fisik Daging Sapi Bali Prarigor Yang Dimarinasi Ekstrak Kakao Pada Waktu Dan Level Berbeda. Universitas Hasanuddin Makasar.

Galih.A., Narwati., dan Sunarko.B, 2016. Penurunan Kadar Pb Pada Kerang Hijau (Mytilus Virids)Dengan Menggunakan Filtrat Tomat (Solanum Lycopersicum). Poltekkes Kemenkes Surabaya.

Lutfillah.K, 2011. Kasus Newmont (Pencemaran Di Teluk Buyat). Jurnal Kybernan. (2) : 1.

Mus.S., Leksono.T, 2004. Studi Mutu dan Preferensi Konsumen Terhadap Marinade Kerang Bulu ( Anadara inequivalvis ). Universitas Riau Pekanbaru.

Palar.H, 2012. Pencemaran dan Toksikologi Logam Berat. Jakarta. Rineka Cipta : $94-114$ 
Purnomowati.I., Hidayati.D., dan Saparinto.C, 2008. Aneka kudapan berbahan ikan. Yogyakarta. Kanisius..

Sakinah, 2013. Efektivitas Larutan Buah Jeruk Nipis (Citrus aurantifolia Swingle.) dan Belimbing Wuluh (Averrhoa bilimbi L.) Dengan Variasi Konsentrasi Dalam Menurunkan Kadar Logam Berat Timbal (Pb) Pada Kerang Bulu (Anadara antiquata). UIN Maulana Malik Ibrahim Malang.

Saputri. R., Rachmadiarti.F., dan Raharjo, 2015. Penurunan Logam Berat Timbal ( Pb ) Ikan Nila (Oreochromis nilotica) Kali Surabaya Menggunakan Filtrat Jeruk Siam (Citrus nobilis ). Universitas Surabaya. LenteraBio ( 4 ) : 136-141.

Standrat Nasional Indonesia No 7387 tahun 2009 tentang Batas Maksimum Cemaran Logam, Berat dalam Pangan

Taftazani.A, 2007. Distribusi Konsentrasi Logam Berat Hg Dan Cr Pada Sampel Lingkungan Perairan Surabaya. PTAPBBATAN : 36-45.
Triyono.A., 2010. Mempelajari Pengaruh Penambahan Beberapa Asam Pada Proses Isolasi Protein Terhadap Tepung Protein Isolat Kacang Hijau ( Phaseolus radiatus L. ) Jurusan Teknik Kimia Universitas Diponegoro Semarang. ISSN : 1411-4216.

Ulfah.S., Rachmadiarti.F., dan Raharjo, 2014. Upaya Penurunan Logam Berat Timbal pada Mystus nigriceps di Kali Surabaya Menggunakan Filtrat Kulit Nanas. Skripsi Jurusan Biologi Universitas Negeri Surabaya (82) : 103-108.

Yanuar.A, 2008. Toksisitas Merkuri di Sekitar Kita. Departemen Farmasi FMIPA-Universitas Indonesia.

Widowati.W., Sastiono. A., Rumampuk.Rymond, 2008. Efek Toksik Logam.Yogyakarta. ANDI Yogyakarta : $1-147$.

Zulkifli.D, 2006. Tinjauan terhadap tailing mengandung unsur pencemar Arsen ( As ), Merkuri ( $\mathrm{Hg})$, Timbal ( $P b)$, dan Kadmium ( $\mathrm{Cd}$ ) dari sisa pengolahan bijih logam. Geologi Indonesia (1) : 3136. 